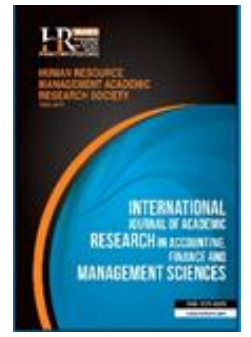

International Journal of Academic Research in Accounting, Finance and Management Sciences

Vol. 10, No.3, July 2020, pp. 52-63

E-ISSN: 2225-8329, P-ISSN: 2308-0337

(c) 2020 HRMARS

www.hrmars.com

To cite this article: Md. Aris, N. Nurhidayah Sokat, N., Sahari, S. (2020). The Moderating Effect of Government Ownership on the Relationship Between Cash Flow and Firm's Performance for Construction Industry in Malaysia, International Journal of Academic Research in Accounting, Finance and Management Sciences 10 (3): 52-63.

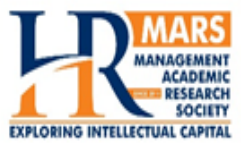

\title{
The Moderating Effect of Government Ownership on the Relationship between Cash Flow and Firm's Performance for Construction Industry in Malaysia
}

\author{
Nazaria Md. Aris ${ }^{1}$, Nurhidayah Sokat ${ }^{2}$, Salawati Sahari ${ }^{3}$ \\ 1,2,3 Faculty of Economics and Business. Universiti Malaysia Sarawak, Kota Samarahan, Sarawak, \\ 3E-mail: ssalawati@unimas.my (Corresponding author)
}

\begin{abstract}
This study attempts to measure the circumference of the cash utilization activities from operations activity, investment activity, and financing activity towards firms' performance of the construction industry in Malaysia by using Government Ownership as the moderating variable. This study essentially using a secondary data that obtain from the annual report for the year 2014 to 2018. The data of the cash flow variable and firms' performance was originally keep recorded in a monetary value whilst data for Government Ownership was obtained through a content analysis. The findings revealed that there is negative relationship with Net Cash Flow towards the Return on Assets. The results demonstrated that the Net Cash Flow in Operating activity is the most influenced by Government Ownership. The Net Cash Flow in Investing activity is significantly affected, while the Net Cash Flow in Financing is the least affected by Government Ownership. In other words, although the government has an authority to influence the economic activity in the market, the government interfere in their capital structure does not effectively affect the firms' performance of construction sector in Malaysia.

Key words Cash Flow, Net Cash Flow in Operating, Net Cash Flow in Investing, Net Cash Flow in Financing, Return on Assets, Government Ownership

\begin{tabular}{ccl}
\cline { 2 - 3 } Received: & 13 Jul 2020 & C The Authors 2020 \\
Revised: & 10 Aug 2020 & Published by Human Resource Management Academic Research Society (www.hrmars.com) \\
Accepted: & 14 Sep 2020 & $\begin{array}{l}\text { This article is published under the Creative Commons Attribution (CC BY 4.0) license. Anyone may } \\
\text { reproduce, distribute, translate and create derivative works of this article (for both commercial and } \\
\text { non-commercial purposes), subject to full attribution to the original publication and authors. The full } \\
\text { terms of this license may be seen at: http://creativecommons.org/licences/by/4.0/legalcode }\end{array}$
\end{tabular}
\end{abstract}

\section{Introduction}

Construction firms become a more challenging field caused by the high potential of project failure compare to the other industries (Shahhosseini et al., 2017). The outcome of this deficiency is the convergence of various variables in the management and financial factors. The cash flow needed to be managed efficiently due to the cycles of growth and capital investment of the company. In other words, the cash flow state of the business is a representation of the performance of the project. The management team must control and structure its cash flow strategically to ensure that all the infrastructure projects are financed and running smoothly until the finishing. The company would be entirely dependent on external financing, which directly puts the company at risk of fluctuating interest rates. Stable cash flow represents the financial flexibility of the firm, which allows it to continue its operation and to achieve higher profitability while enabling firms to diversify their investments. The construction industry is beginning to destabilise in 2014. Developers had to plan strategic budgeting by buying raw materials when there was an affordable offer to remain in the competition for a period of time. But there is a high tendency of delayed 
projects due to the material used when the material used is low price with low quality. Hence, failure to accept the market value can trigger in a contract value will be too minimal imposed within the infrastructure phase. In this fluctuated demand, the developers must restructure and transform the marketplace by resolving the reduced long term within a dateline for implementation, over budgeting, protecting the rights of contractors and laborers, as well as growing the overall consequences of the green practices. At present, the weak construction sector has been expressed in a challenging tendering environment for infrastructure work, including some developers who have been tempted to lower prices to draw new customers. It's a difficult and competitive market for the tendering process. Approximately over 100 developers are bidding the same deal. The mature construction developers were willing to accept the tender in low-scale categories only to hold across the competitive business environment. One construction company behaving in this way would not corrupt the entire sector, but other contractors would feel the strain of the volatile property market.

According to Malaysia's National Expenditure Planning in 2019, the construction industry in Malaysia is suffering from the intensely challenging in pricing, rising infrastructure raw material, and dominant resources. The construction industry is trying to find ways with the "East Coast Rail Link" (ECRL's) and analysts are still forecasting a loss of momentum in the construction industry, with 4.9 percent growth in 2019 (Nian, 2019). The "Pocket Quarter 1 Stat" by the Department of Statistics Malaysia also mentioned that construction industry growth in Malaysia was comparatively low (Ev, 2019). Not only this detrimental the business sector, but construction, as a major industry, is hamstringing the country's growth. There is so much common obstacle for the construction company that needs to be considered particularly for the difficulties of the workforce with a high unemployment rate. The rate of change in unemployment in Malaysia was 3.25\% and 3.36\% respectively between 2010 and 2018 (Department of Statistics, 2018). It is pale by 2.3 and 2.2 relative to the same year estimates in Singapore. It shows a decline in Singapore while inclination for Malaysia (Aman, 2019). Losing skill manpower combined with the pressure of the national economic recession force the construction industry to improve its strategy in the competition. In addition, because of the lower attention to cash management, other issues like wages are contributing to the low productivity of construction firms in Malaysia. Narrow selection of regional contracts stabbed the workers to build their skills. And, the fragility of regulations that partially disturbed the productive. Considering the nation's volatility nowadays, fuel costs were expected to continue to rise amid multinational threats as well. On the only certain side, construction companies perceive ambiguity as a stronger force than high costs. That is when the cost of a contract is determined by a vendor. If the contract has no volatility provision, the vendor is required to endure the burden of any cost movements. The developer being placed in such a riskier point in an environment whereby the cost in the market is violent and volatile. Market value for volatility uncertainty would result in greater contract costs. Government intervention on the cost of the fuel price is tied to the world market level. All these matters are derived from how the company executed its finances to cover all the expenditure and uncertainty. As a result, cash flow is extremely important to the firms to survive and a firm with stable cash flow will heighten the company return. For these reasons, the purpose of this study is to understand the relationship between cash flow and firms' performance proxied by ROA with the inclusion of government ownership as the moderating variable of the construction industry in Malaysia. In general, this study aims to develop the relationship between the cash flow and profitability on construction industry listed in Bursa Malaysia as with the moderating effect of government ownership. Bursa Malaysia. Specifically, this study commences on the following objectives to:

- investigate if the cash flow from operating activities affects the firm's profitability

- ascertain whether the cash flow from investing activities has effect on the firm's profitability

- identify if the cash flow from financing activities has impact on the firm's profitability

- determine whether the moderating effect of government ownership strengthen or weaken this relationship.

\section{Literature review}

\subsection{Cash Flow and Firms' Performance Relationship}

Cash is required for a business organization to funding its nature activities. Cash can be obtaining from internal sources or external sources. Nevertheless, cash is the main issue of disturbance for most of 
the company because it involves few parties in the operations activity. It is not solely about the internal management of the company, but also outside party such as investor and clients. By neglect the underperformed of return margin of the company will cause a short of cash. Then, most of the company will decrease their product which directly decrease their revenue but increase their cliental attention. An optimal solution for a company to retain their profitability is by having enough cash earning because of its function on the instantaneous action. Profitability is different with the benefit since it is a monetary value while benefit can be derived from the image and brand reputation of the company. Without profitability, the company can't survive in the industry but with the beneficial of non-monetary value the company still can survive by doing the unprofitable purposed organization. That is why the company present a different amount in the financial statement; it is a combination of the financial return and benefit value which might confuse the potential investor.

Therefore, the investor should investigate in detail the figure and the activity of the company to recognize the company transparently before invested in the company. There are two elements of cash flow, which is inflow and outflow (Omopariola et al., 2019). Cash inflows are extracted from the operations and maintenance, investment and financing activities of the company like obtaining a loan from a bank, enhanced bank repayments, investor capital expenditure, reinvestment value, and consumer fee for products or servicing. Cash outflows typically involve compensation for workers, lease and routine operational costs, equity investments, manufactured goods and equipment, shares return and interest on debt, settlement of borrowing, and acquire of Non-current component including plant equipment, transportation and working appliances. Category of cash flow is in two types which is positive and negative. Positive cash flow emerges once the revenue of the company reaches its expenditure and it is providing an illustration of solid financial performance for the company. While, negative cash flow arises just as the capital expenditure exceeds the revenue and is reflective of a financially unstable. Profitability generated from the activity establish by a company after settling all the fixed and variable cost (Hanafi et al., 2018). The money generated returns to the investors of the company, who might or might not prefer to spend it in maintaining the business. Thus, profitability reflects the company's capability in making revenue from the resources obtain for being use. It will reveal the way that company handle and regulated their resources to gain high earnings. The efficiency of resources utilization will give high profitability. Lyngstadaas (2019), the main objective of companies is to earn profitability which eventually will demonstrate its achievement to sustain in the industry. The smaller the revenue size, the lower the concerns of the financial performance. Wherefore, the lessen of company return, the lessen the company striving for its achievement. By controlling the financial resources allow the company to earned high profitability.

\subsection{Moderating Effects of Government Ownership}

Malaysian construction industry is one of the most important sectors in meeting the growing demand of the population basic needs and rapid economic development. Typically, it can be owned and operated by governments or private companies. The percentage of ministry authority in the company will determine how the performance of the company in term of management and arrangement (Zuoping, 2011). Several studies were conducted in Malaysia to define the features of government interference that improves company's decision-making. The empirical studies offer mixed conclusions on the position of Government Ownership of monitoring the management of a business (Ang \& Ding, 2006; Feng et al., 2004; Qiang, 2003). The government-linked companies (GLCs) in Singapore have more valuations and better governance of its businesses than those non-GLCs (Ang \& Ding, 2006). The study on thirty Singaporean GLCs from 1964 to 1998 indicated that the privatisation of share-issues have some positive impact on a company's performance but there was no evidence of lower profitability than the non-GLCs with the same size and industry (Feng et al., 2004). Nevertheless, Mak \& Li (2001) argued that GLCs may have less motivation to manage agency issues because they have less responsibility for financial results, easier access to funding, less market visibility for corporate management, and weaker shareholder monitoring. Also, opportunistic actions can occur in companies with a high percentage of government shares due to political pressure (Gill-de-Albornoz \& Illueca, 2005). This study provides rational explanations why the government generally fulfils its function as an internal supervisory structure in which the involvement of government control is supposed to help improve the monitoring process of the organisation. 


\section{i. Cash Flow in Operating Activity}

According to Hoang et al. (2019) the operating cash flow is maintaining firms' performance through the cash generate from daily activity. Zuoping (2011), if the operating output of the firm level is high, it is significantly increasing the firms' performance. Cash flow indicators lead to additional details and boost the base model's forecast output. Hence, this hypothesis proposed to investigate whether the cash flow in operating will affect the firms' performance by considering a government ownership as a moderate variable. Therefore, the first hypothesis can be developed as;

$H_{1}$ : The cash flow in operating activity and firms' performance affects negatively with high moderating effect of government ownership.

\section{ii. Cash Flow in Investing Activity}

Lu \& Jhuang (2014), the development of a firm is depending on the stockholder contribution percentage. That cash inflow from the external sources exposes the firm to aggrandizement although the firm is still immature in the industry and limited in the output volume, as a result, big scale of firm cannot perform well due to the conglomerate effect. The imperfection in the capital market controls the activities of cash which motivated to the profitability. Hence, this hypothesis proposed to investigate whether the cash flow in investing will affect the firms' performance by considering a government ownership as a moderate variable. Thus, the second hypothesis is constructed as;

$\mathrm{H}_{2}$ : The cash flow in investing activity and firms' performance affects negatively with moderate effect of government ownership.

\subsection{Cash Flow in Financing Activity}

Tucker et al. (2015), Budget stability and adequate corporate cash flow improve both efficiency and productivity. Consistently found that funding accessibility and adequate corporate cash flow enhance productivity intensify the company profitability. The stronger cash flow position, might substantially forecast the efficiency, is the accessibility of funds in forms of current asset as well as project availability and the competitiveness of construction team. Conflict of cash flow delayed arbitration may lead in relinquishment of infrastructure activity while having a high charge on the borrowing. Hence, this hypothesis proposed to investigate whether the cash flow in financing will affect the firms' performance by considering a government ownership as a moderate variable. Based on the discussions, the third hypothesis is constructed as;

$H_{3}$ : The cash flow in financing activity and firms' performance affects negatively with low moderating effect of government ownership

\section{Methodology of research}

Khalid et al. (2012), research design for this study is established to presents both the research question and the methodology used to collect empirical support on this research. This study essentially uses panel data regression to illustrate the secondary data that obtain from Bursa Malaysia. It is generated from the annual report for the year 2014 until the year 2018. According to the hypothesis proposed for this study there are two type of level of measurement of data use which is Interval and Nominal. Stevens (2009) stated that, the three divisions of cash flow and Return on Assets is an interval since income is a continuous numbering value which 0 and negative value is also considered as income.

Thus, the data of the cash flow variable and firms' performance was originally keep recorded in a monetary value. Whereas, Government Ownership is a Nominal which will be asses in the Content Analysis Approach where it's only need number 1 represent for existing of government ownership while 0 is nonexisting of government ownership. In this study, the performance of the construction firm is measured with Return on Assets as the independent variable while Net Cash Flow in Operating, Net Cash Flow in Investing and Net Cash Flow in Financing are the independent variables. The Government Ownership is the moderating variable. The theoretical model of study is shown in Figure 1 hold to support several theories to this study namely Free Cash Flow Theory, Dynamic Theory, Innovative Theory, Risk Theory, Uncertainty Bearing Theory and Rent Theory of Profit. 


\section{Independent Variable}

\section{Dependent Variable}

\begin{tabular}{|c|}
\hline $\begin{array}{c}\text { Return on } \\
\text { Assets }\end{array}$ \\
\hline
\end{tabular}

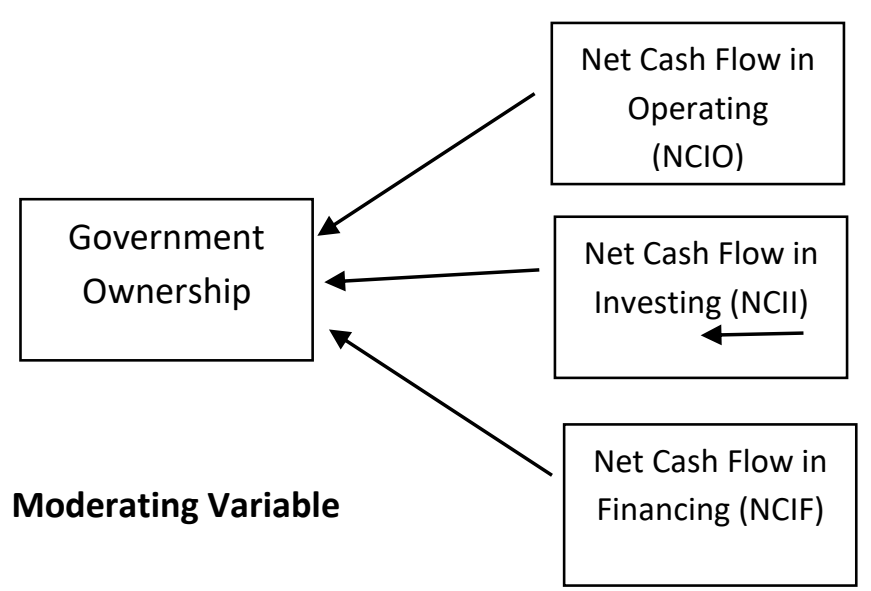

Figure 1. Theoretical Model

\section{Findings}

\subsection{Descriptive Analysis}

By referring to Table 1, there are 200 samples will be test according to the checking procedure of moderation analysis. The samples are according to 40 companies that represent by 4 variables within 5 years. Therefore; 40 companies multiply by 5 years $=200$. The difference between the average for independent variable which is Net Cash Flow in Operating ( $\mathrm{NClO}$ ), Net Cash Flow in Investing (NCII) and Net Cash Flow in Financing (NCIF) is quite notable. NCIO with the value of RM15903021.2850 and NCIF is 34447387.1850 . There is $46.17 \%$ value difference of which almost half of the NCIF. The difference of NCII, however, is very high compare to $\mathrm{NCIO}$ and net NCIF with the negative value of -2123726.1850 . Return on Assets (ROA) is second lowest average value of 1.60 and dispersion value of 36.65 since it was presented in the form of percentage. This 1.60 indicate that the returns of on each asset is to low but still positive. This means, the sample presented by companies are performing well with profitability, but the asset generates only $36 \%$ return to the profits. Lastly, Government Ownership (GO) which is the moderated variable has the lowest among others because of the data presented in a content analysis technique which only incur a value of 0 and 1 in the sample for testing analysis.

Table 1. Descriptive Statistics for NCIO, NCII, NCIF, ROA and GO

\begin{tabular}{|l|c|c|c|}
\hline Descriptive Statistics & \multicolumn{4}{|c|}{ Mean } & Std. Deviation & N \\
\hline & 1.6071 & 36.65795 & 200 \\
\hline Return on Assets (\%) & 15903021.2850 & 85638733.10855 & 200 \\
\hline Net Cash In Operating (RM) & -2123726.5700 & 163781999.51039 & 200 \\
\hline Net Cash In Investing (RM) & 34447387.1850 & 152307132.67794 & 200 \\
\hline Net Cash In Financing (RM) & .38 & .487 & 200 \\
\hline Government Ownership (x) & & &
\end{tabular}

Table 2 shows ROA has a weak relationship to the consolidation of NCIO, NCII and NCIF of only $0.3 \%$ (0.003). Which means, each independent variable is not related to each other and enable to differentiate the relationship of each independent variables towards ROA? There is also a low variation when the $\mathrm{NCIO}$, $\mathrm{NCI}$ and NCIF combined with GO towards ROA with the value of $0.8 \%(0.008)$. While the adjusted R square value of -0.012 shows that, for the combination model proposed with the moderated variable is poorly predicted of the outcome. The negative $R$ square of -0.012 indicates that, when the company is a GO, the ROA would be lower. However, there is an additional of $0.5 \%$ of variance to the ROA when the R square change included. If the model is separated with the $\mathrm{GO}$, the interaction of the variables explained only has an additional of $0.3 \%$ variance in the ROA. Hence, the proposed model is insignificant contribution since the value of Sig. $F$ change is declining from $F=0.915$ to $F=0.303$ when the $\mathrm{GO}$ is injected to the regression model. 
This reject the findings of Sune, (2015) where, highly concentrated ownership is expected to be more effective in analysing company performance.

Table 1. Relationship between NCIO, NCII and NCIF with the predictors of ROA

\begin{tabular}{|c|c|c|c|c|c|c|c|c|c|}
\hline \multirow[b]{2}{*}{ Model } & \multirow[b]{2}{*}{$\mathbf{R}$} & \multirow[b]{2}{*}{ R Square } & \multirow{2}{*}{$\begin{array}{l}\text { Adjusted } \\
\text { R Square }\end{array}$} & \multirow{2}{*}{$\begin{array}{c}\text { Std. Error of } \\
\text { the } \\
\text { Estimate }\end{array}$} & \multicolumn{5}{|c|}{ Change Statistics } \\
\hline & & & & & $\begin{array}{l}\text { R Square } \\
\text { Change }\end{array}$ & F Change & Df1 & Df2 & $\begin{array}{l}\text { Sig. F } \\
\text { Change }\end{array}$ \\
\hline 1 & $.051^{a}$ & .003 & -.013 & 36.88899 & .003 & .172 & 3 & 196 & .915 \\
\hline 2 & $.090^{\mathrm{b}}$ & .008 & -.012 & 36.88283 & .005 & 1.066 & 1 & 195 & .303 \\
\hline
\end{tabular}

In the below Table 3, it indicates the test was conducted in order to answer the general objective of this study by differentiate the two predictors group of independent variables which is with or without GO. In this study, is to develop the relationship between the $\mathrm{NCIO}, \mathrm{NCIF}$ and $\mathrm{NCIl}$ towards ROA and the moderating effect of $\mathrm{GO}$. Therefore, the proposed model is insignificant predictor of ROA as there were no statistically significant differences between group means since $p=0.812$ and $F$ ratio of 0.39 which greater than 0.005 .

Table 2. Analysis of Variance between NCIO, NCll and NCIF towards ROA with the moderation effect of GO

\begin{tabular}{|c|c|c|c|c|c|c|}
\hline \multicolumn{7}{|c|}{ Anova $^{a}$} \\
\hline Mode & & Sum of Squares & Df & Mean Square & $\mathbf{F}$ & Sig. \\
\hline \multirow{3}{*}{1} & Regression & 700.910 & 3 & 233.637 & .172 & $.915^{\mathrm{b}}$ \\
\hline & Residual & 266716.342 & 196 & 1360.798 & & \\
\hline & Total & 267417.252 & 199 & & & \\
\hline \multirow{3}{*}{2} & Regression & 2150.380 & 4 & 537.595 & .395 & $.812^{\mathrm{c}}$ \\
\hline & Residual & 265266.872 & 195 & 1360.343 & & \\
\hline & Total & 267417.252 & 199 & & & \\
\hline \multicolumn{7}{|c|}{ A. Dependent Variable: ROA } \\
\hline \multicolumn{7}{|c|}{ B. Predictors: (Constant), NCIF, NCIO, NCII } \\
\hline \multicolumn{7}{|c|}{ C. Predictors: (Constant), NCIF, NCIO, NClI, GO } \\
\hline
\end{tabular}

$F(7,195)+0.39, P=0.812>0.005$

\subsection{Coefficients}

Table 4 indicates that, $\mathrm{NClO}=0.981, \mathrm{NCll}=0.792, \mathrm{NClF}=0.540$ and $\mathrm{GO}=0.303$ are significantly contributed to the model towards return on asset as the dependent variable. This finding explains that each of the cash flow have a significant positive impact towards the performance. When there are positive cash flows, the firms' performance would increase.

Table 4. Coefficients between NCIO, NCII and NCIF towards ROA with the moderation effect of GO

\begin{tabular}{|c|c|c|c|c|c|c|c|c|c|c|}
\hline \multicolumn{11}{|l|}{ Coefficients } \\
\hline \multirow{2}{*}{ Model } & \multicolumn{2}{|c|}{$\begin{array}{l}\text { Unstandardized } \\
\text { Coefficients }\end{array}$} & \multirow{2}{*}{$\begin{array}{c}\begin{array}{c}\text { Standardized } \\
\text { Coefficients }\end{array} \\
\text { Beta }\end{array}$} & \multirow{2}{*}{$\begin{array}{ll}T \\
\end{array}$} & \multirow{2}{*}{ Sig. } & \multicolumn{3}{|c|}{ Correlations } & \multicolumn{2}{|c|}{$\begin{array}{l}\text { Collinearity } \\
\text { Statistics }\end{array}$} \\
\hline & B & Std. Error & & & & $\begin{array}{l}\text { Zero- } \\
\text { order }\end{array}$ & Partial & Part & Tolerance & VIF \\
\hline (Constant) & 1.915 & 2.713 & & .706 & .481 & & & & & \\
\hline $\mathrm{NClO}$ & $3.406 \mathrm{E}-9$ & .000 & .008 & .110 & .913 & .009 & .008 & .008 & .967 & 1.034 \\
\hline $\mathrm{NCll}$ & $5.522 \mathrm{E}-9$ & .000 & .025 & .340 & .734 & .029 & .024 & .024 & .967 & 1.034 \\
\hline $\mathrm{NCIF}$ & $-1.018 \mathrm{E}-8$ & .000 & -.042 & -.590 & .556 & -.043 & -.042 & -.042 & .989 & 1.011 \\
\hline (Constant) & -.143 & 3.366 & & -.042 & .966 & & & & & \\
\hline $\mathrm{NClO}$ & $-7.357 \mathrm{E}-10$ & .000 & -.002 & -.024 & .981 & .009 & -.002 & -.002 & .951 & 1.051 \\
\hline $\mathrm{NCII}$ & $4.304 \mathrm{E}-9$ & .000 & .019 & .264 & .792 & .029 & .019 & .019 & .962 & 1.039 \\
\hline $\mathrm{NClF}$ & $-1.059 \mathrm{E}-8$ & .000 & -.044 & -.613 & .540 & -.043 & -.044 & -.044 & .989 & 1.011 \\
\hline GO & 5.620 & 5.444 & .075 & 1.032 & .303 & .075 & .074 & .074 & .974 & 1.027 \\
\hline
\end{tabular}

a. Dependent Variable: ROA

Comparing between the three types of cash flows, the $\mathrm{NClO}$ indicates the highest significant impacts towards ROA with $98 \%$ effects towards performance. This is consistent with the viewpoint of (Agyei- 
Boapeah \& Machokoto, 2018) where, operations is the most activity influence the business risk. However, the additional of the $\mathrm{NCIO}$ and NCIF change in the slope affect for one-unit increase in will decrease the value of ROA of RM7.35 and RM 1.05 respectively. Whereas, the additional of NCIl and GO will increase the return on asset for RM4.3 respectively. While the value if collinearity statistics obtain VIF value between 1 to 10 and the tolerance score to be above 0.2 which indicates that, there is no multicollinearity symptoms. Therefore, there is no independent variables should be removed and this model takes the form of a statistical multiple linear equation where:

$\mathrm{ROA}=0.966-7.35+4.30-1.05+5.62+\varepsilon_{\mathrm{t}}$

Therefore, $R O A=-73.6031-7.35 \mathrm{NCIO}+4.30 \mathrm{NCII}-1.05 \mathrm{NCIF}+5.62 \mathrm{GO}$

From the equation, the coefficient of $\mathrm{NCIO}=-7.35$, denotes that for every $1 \%$ increase in the Net cash flow in operating in a firm will decreasing the return on asset by $7.35 \%$. 0 . This indicated that, there are negative relationships between Net cash flow in operating with the return on asset. Besides, the coefficient of NCII= +4.30 , indicates that when $\mathrm{NCII}$ increase by $1 \%$, the ROA will be expected to increase by $4.3 \%$. Hence, there are positive relationships between NCII with the ROA. The coefficient of $\mathrm{NCIF}=1.05$, means that for every $1 \%$ increase in the NCIF in a firm will decrease the return on asset by $1.05 \%$. This indicated that, there are negative relationships between Net cash flow in Financing with the return on asset. The coefficient of $\mathrm{GO}=5.62$. This represents that for every $1 \%$ increase in the Government Ownership in will lead to an increasing of ROA by $3.416 \%$. This indicated that, there are positive relationship between $\mathrm{GO}$ with the return on ROA. In overall, NCIO, NCIF, NCII and GO has a relationship with return on asset independently. But only NCII has a negative relationship to the ROA while the rest are having a positive relationship toward ROA.

\subsection{Coefficient Correlations Analysis}

By referring to the Table 5 it shows a statistical measure of the strength to the relationship between the relative movements of two independent variables. In this case, it is emphasizing on the GO that act as moderated variables are poor negatively associated with $\mathrm{NCIO}$ with the value of $-0.128, \mathrm{NCll}$ with the value of -0.073 and the NCIF with the value of -0.23 . The values range of these independent variable fall in the between -1.0 and 1.0 which indicates, no symptom of error in correlation measurement. Therefore, it is an advisable variable to be as a moderating variable to the proposed regression model. So that, it can differentiate from the proposed independent variables and be tested without any influential error. Furthermore, NCIF has a weak negatively correlated to the $\mathrm{NCIO}$ with the value of -0.74 but positively correlated with $\mathrm{NCll}$ with the value of 0.081 . Whereas, $\mathrm{NCIO}$ weak negatively correlated to the $\mathrm{NCII}$ with the value of -0.157 .

Table 5. Coefficient Correlations between NCIO, NCII and NCIF towards ROA with the moderation effect of GO

\begin{tabular}{|c|c|c|c|c|c|c|}
\hline \multicolumn{7}{|c|}{ Coefficient Correlations } \\
\hline \multicolumn{3}{|l|}{ Model } & $\mathrm{NClF}$ & $\mathrm{NClO}$ & $\mathrm{NCll}$ & GO \\
\hline \multirow{6}{*}{1} & \multirow{3}{*}{ Correlations } & $\mathrm{NClF}$ & 1.000 & -.078 & .080 & \\
\hline & & $\mathrm{NClO}$ & -.078 & 1.000 & -.169 & \\
\hline & & $\mathrm{NCll}$ & .080 & -.169 & 1.000 & \\
\hline & \multirow{3}{*}{ Covariances } & $\mathrm{NClF}$ & $2.979 \mathrm{E}-16$ & $-4.171 \mathrm{E}-17$ & $2.235 \mathrm{E}-17$ & \\
\hline & & $\mathrm{NClO}$ & $-4.171 \mathrm{E}-17$ & $9.638 \mathrm{E}-16$ & $-8.499 \mathrm{E}-17$ & \\
\hline & & $\mathrm{NCII}$ & $2.235 \mathrm{E}-17$ & $-8.499 \mathrm{E}-17$ & $2.636 \mathrm{E}-16$ & \\
\hline \multirow{8}{*}{2} & \multirow{4}{*}{ Correlations } & $\mathrm{NClF}$ & 1.000 & -.074 & .081 & -.023 \\
\hline & & $\mathrm{NClO}$ & -.074 & 1.000 & -.157 & -.128 \\
\hline & & $\mathrm{NCII}$ & .081 & -.157 & 1.000 & -.073 \\
\hline & & GO & -.023 & -.128 & -.073 & 1.000 \\
\hline & \multirow{4}{*}{ Covariances } & $\mathrm{NClF}$ & $2.980 \mathrm{E}-16$ & $-4.009 \mathrm{E}-17$ & $2.282 \mathrm{E}-17$ & $-2.179 \mathrm{E}-9$ \\
\hline & & $\mathrm{NClO}$ & $-4.009 \mathrm{E}-17$ & $9.796 \mathrm{E}-16$ & $-8.022 \mathrm{E}-17$ & $-2.184 \mathrm{E}-8$ \\
\hline & & $\mathrm{NCII}$ & $2.282 \mathrm{E}-17$ & $-8.022 \mathrm{E}-17$ & $2.649 \mathrm{E}-16$ & $-6.426 \mathrm{E}-9$ \\
\hline & & GO & $-2.179 E-9$ & $-2.184 \mathrm{E}-8$ & $-6.426 \mathrm{E}-9$ & 29.638 \\
\hline
\end{tabular}




\subsection{Collinearity Diagnostics}

Table 6 shows the eigenvalues result for this model is more than 0 which indicates that, the predictors are highly correlated and that small changes in the data values of eigenvalues may influence to the substantial transition in the estimates of the coefficients. In other words, the collinearity diagnostics confirm that there is no multicollinearity problem occurs. While, there is no collinearity problem shows by the condition index because all the values generated is less than 15 for data set.

Table 3. The Eigenvalues Result

\begin{tabular}{|c|c|c|c|c|c|c|c|c|}
\hline \multicolumn{9}{|c|}{ Collinearity Diagnostics } \\
\hline \multirow{2}{*}{ Model } & \multirow{2}{*}{ Dimension } & \multirow{2}{*}{ Eigenvalue } & \multirow{2}{*}{ Condition Index } & \multicolumn{5}{|c|}{ Variance Proportions } \\
\hline & & & & (Constant) & $\mathrm{NClO}$ & $\mathrm{NClI}$ & NCIF & GO \\
\hline \multirow{4}{*}{1} & 1 & 1.347 & 1.000 & .27 & .21 & .01 & .20 & \\
\hline & 2 & 1.123 & 1.095 & .02 & .15 & .54 & .14 & \\
\hline & 3 & .783 & 1.312 & .14 & .19 & .30 & .58 & \\
\hline & 4 & .748 & 1.342 & .56 & .46 & .15 & .08 & \\
\hline \multirow{5}{*}{2} & 1 & 1.834 & 1.000 & .13 & .06 & .00 & .05 & .13 \\
\hline & 2 & 1.123 & 1.278 & .01 & .17 & .54 & .11 & .00 \\
\hline & 3 & .896 & 1.431 & .06 & .18 & .00 & .64 & .08 \\
\hline & 4 & .772 & 1.541 & .00 & .58 & .44 & .18 & .00 \\
\hline & 5 & .375 & 2.211 & .80 & .00 & .01 & .01 & .79 \\
\hline \multicolumn{9}{|c|}{ A. Dependent Variable: ROA } \\
\hline
\end{tabular}

\subsection{Residuals Statistics}

Table 7 shows the test was conducted in order to answer all specific objective which is to test the relationship between to develop the relationship between the NCIO, NCIF and NCII towards ROA and the moderating effect of GO.

Table 4. Residuals Statistics ${ }^{\mathrm{a}}$

\begin{tabular}{|l|c|c|c|c|c|}
\hline Residuals Statistics $^{\mathrm{a}}$ & Minimum & Maximum & Mean & Std. Deviation & N \\
\hline Predicted Value & -22.0050 & 7.1386 & 1.5712 & 3.31096 & 199 \\
\hline Std. Predicted Value & -7.121 & 1.682 & .000 & 1.000 & 199 \\
\hline Standard Error of Predicted Value & 3.351 & 33.618 & 4.704 & 3.504 & 199 \\
\hline Adjusted Predicted Value & -128.8804 & 7.0427 & .8790 & 9.89336 & 199 \\
\hline Residual & -452.79495 & 187.34341 & .00000 & 36.59741 & 199 \\
\hline Std. Residual & -12.247 & 5.067 & .000 & .990 & 199 \\
\hline Stud. Residual & -12.302 & 5.122 & .006 & 1.000 & 199 \\
\hline Deleted Residual & -456.88568 & 191.39160 & .69221 & 38.15085 & 199 \\
\hline Stud. Deleted Residual & -26.165 & 5.493 & -.063 & 1.927 & 199 \\
\hline Mahal. Distance & .632 & 162.707 & 3.980 & 16.400 & 199 \\
\hline Cook's Distance & .000 & 2.021 & .013 & .145 & 199 \\
\hline Cantered Leverage Value & .003 & .822 & .020 & .083 & 199 \\
\hline A. Dependent Variable: ROA & \multicolumn{7}{|l}{} \\
\hline
\end{tabular}

\subsection{Content Analysis}

Content Analysis approach has been applied into the multiple regression model to develop the relationship between the $\mathrm{NCIO}, \mathrm{NCIF}$ and $\mathrm{NCI}$ towards $\mathrm{ROA}$ and the moderating effect of GO. It is applied to government ownership because the data gathered for this variable is only represent by two category of number which is 1 and 0 . Number 1 represent for existing of government ownership while 0 is non-existing of government ownership. The data was generating from the analysis of shareholding included in the annual report of each company. Figure 2 shows how GO impact the ROA by Net Cash Flow of construction firm listed in Bursa Malaysia from 2014 until 2018. The results indicate 35.50\% of construction firms in Malaysia possess government ownership in their capital structure while the $64.50 \%$ doesn't have any 
government ownership in their capital. Thus, content analysis applied for this analysis assist the statistical analysis conducted because the scale of data used for all variable are not similar.

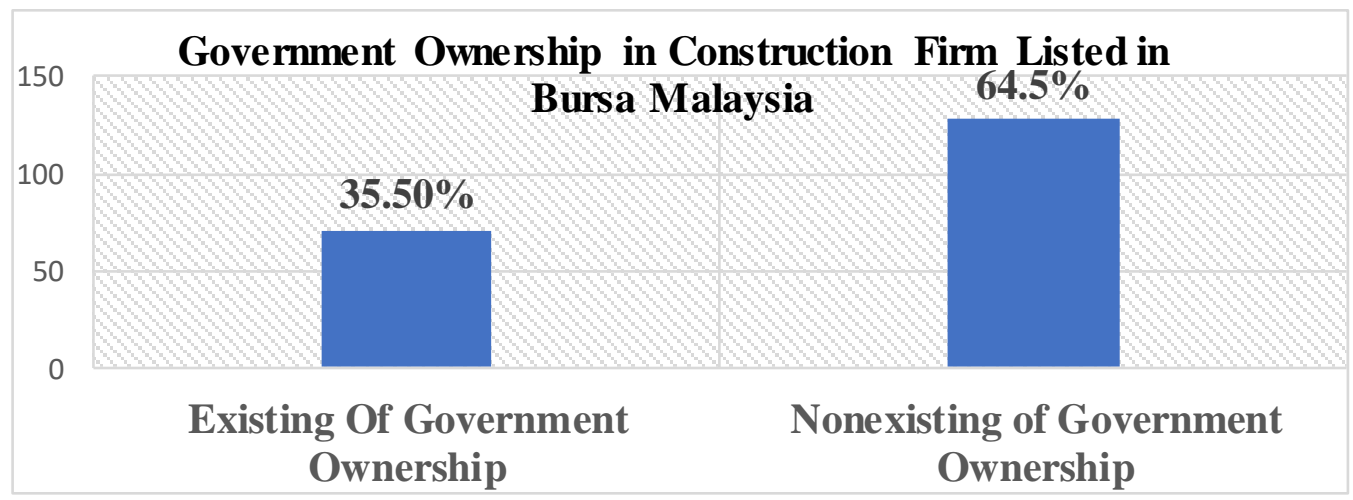

Figure 2. Government Ownership in Construction Firm Listed in Bursa Malaysia

As a conclusion from the result above, The $\mathrm{NCIO}$ is negatively related to the firms' performance and the moderation effect of $\mathrm{GO}$ is high. Hypothesis 1 is rejected since it is statistically insignificant at $5 \%$ significant level. This decision refuses the statement of Hoang et al. 2019 which stated that increasing in $\mathrm{NClO}$ maintained the firms' performance in daily activities. Instead, the optimum cash in a firm is the main strength that allows the firm continuously to operate. Because, profitability from a construction project usually delays in payment, therefore it needs a strong level of cash to cover all the expenses incurred within the payback period. The successful or failure of project does not depend on the government. The real function of government is only as an authority that can control the policy but government are not fully control the project budgeting. Therefore, this result is not relying to the explanation of Free Cash Flow Theory and Dynamic Theory.

Next, based on the statistical analysis conducted, the NCII has a negative association with the firms' performance when the government ownership is moderate. Hence, the hypothesis 2 is rejected too as the conclusion supports the research finding by Huang et al. (2018) where the injection of government fund into the investment activity does not purely lead to effective firms' performance. Besides, it depends on how long government being in the firm as a guarantee for the firm in term of payback. As a result, stakeholders or other financial institution are more convinced that their capital has been secured by the existence of government. This is due to image and trustworthiness bring by government improved the confidence of investors. The firms' performance is not fully controlled by the authority of the investors as mentioned by statement of Lu \& Jhuang (2014). Hence, the Theory of Free Cash Flow and Risk Theory are consequential to the result generated.

Finally, the result indicates there is a negative relationship between NCIF and firms' performance and GO has the lowest moderation effect on this activity. The efficiency of the firm is not strictly because of the government interference into its cash flow budget structure as agreed by Hanafi et al. (2018). However, its assist the statement by Nagar and Raithatha (2016) that higher percentage of government authority in the cash flow structure of a firm would lower the firms' performance. Their result suggests that high cash flow and leverage reflects the high potential for agency conflicts, which leads to lower stock performance. Meanwhile, the board member's complacency is considerably or linked to the budgeting structure and capital investing. Hence, due to the Uncertainty Bearing Theory, risk is very unpredictable even though there is a strong authority in charge for any capital structure of a firm.

\section{Conclusions}

This study aims to understand the relationship between cash flow and firms' performance towards the construction industry listed in Bursa Malaysia by using government ownership as the moderating variable. Overall, the results of the study indicate there is a negative relationship NCIO, NCII and Net NCIF towards firms' performance and the moderating effect of GO varies among the activities. NCIO activity is the most influenced by GO. GO has the highest moderating effect on $\mathrm{NClO}$, followed by moderate effect in $\mathrm{NCll}$ and the lowest moderating effect on NClF. The findings imply that government authority does not 
completely control all relevant issues relating to the construction operating, investing and financial activities that emerge in the construction sector. In other words, while the government interferes as a policymaker and regulator in the mass economic operating activities of the construction firms, the real situations of the construction company's cash flow suffering in the raw material pricing system and dominant capital are not directly due to government ownership. The results thus emphasize that the effectiveness in controlling the firms' cash flow in investing activity is not solely dependent on the presence of government involvement of their capital structure, but may be advantageous for other aspects, such as project tendering and corporate image. Additionally, the firms' performance is not fully controlled by the government ownership in financing activities that include the inflow and outflow of cash from investors. There are other activities that impact the long-term liabilities and equity of the firm. Government intercede in a construction industry might be advantageously in term of payment confirmation, project scale or tighten the public relations to the firms but there is no certainty to confirm the effectiveness of the firms' performance if the government interfere in their capital structure.

This study has several limitations. Some of the annual report is still in a modifying process even though the report supposedly disclosed in two years before the current year. For the financial information, it was still can be track because the financial report will be presented in the form of two consequences year due to the riskier industry along the five years' period allocated for this study. But, if the other report such as shareholdings analysis, it might be difficult to define accurate information when there is no current report provided because the shareholder of a company will change over time. Secondly, there was less information on how government play their role in a construction company as a shareholder. In fact, there is confusion on the government representative name that might influence the overlooked on the government ownership in a shareholder listed. In addition, the previous study that discussed on the government ownership as a moderating analysis to the cash flow towards return on asset are still at inferior stages, which lead to difficulty for this study to compare and contrast the findings, analysis that have been made and supporting literature for discussion part. Due to the worldwide COVID-19 pandemic in 2020, there is a huge impact on the current firms' performance. Hence, suggesting the future research by extending this research to include this year of data into the data period. And, extend the period into longer period to shows the perfect direction of the result and easily to be interpreted. It could also be interesting to find out how the government ownership affected the relationship between cash flow towards firms' performance if any natural phenomenon disaster happening. This will be a beneficial information to all the related parties especially for a construction company on how the management use a limited resources of cash flow to finance all the activity after the COVID -19 is over and being a reference for a beginner company to get ready for any uncontrolled risk. Suggested research might be assumed to have difference significant results with the current finding since COVID-19 pandemic has a huge effect on all the industry around the world. Additionally, researcher may find how the changes of the world economic stability response to the cash flow of the company in order to utilize a limited resource as a lot of construction project was dismissed during a Movement Control Order (MCO) imposed by the government. Also, this research will show whether, which part of the cash flow of the company is more correlated to the firms' performance by moderating of government ownership.

\section{Significant Contribution}

This study contributes to an understanding of the literature on the association between cash flow and listed firms' performance from the perspective of government ownership as moderating effects in the dynamic construction industry in Malaysia. First, the current study adds to the growing accounting literature on cash flow statements by arguing that the government ownership monitoring effect could strengthen the operating, investing, and financing activities of companies towards firms' performance. Second, this study provides insights into the Theory of Free Cash Flow and the literature on ownership structure. The results from the analysis demonstrated the interaction effect of government ownership and efficient use of free cash flow mainly from operating activities is essential for firms' performance. Apart from an extension in the scope of the current literature, it could be seen that this study uncovers the critical areas of managing the three apportionments of firms' cash flow activities such as operating, investing, and financing to improve firms' performance by choosing government ownership as the 
moderating variable. The cash flow ratios used in the financial analysis to evaluate the financial performance influenced the managerial decisions to participate in the company's business activity that affect its liquidity. Besides, the company's financial manager that applies the recommended approach from this study will be able to actively participate in the country's business activities regardless of unstable rising costs and cash constraints faced by the construction industry around the globe. The findings of this study will contribute greatly to the construction industry considering that government ownership plays an important role in controlling firms' cash movement to earn high profitability by strategically solve the problem such as late debt settlement, inadequate cash for project finance and many other monetary issues. Thus, this provides a novelty to this study that many other researchers were not able to explore.

\section{Acknowledgement}

This research is supported by Fundamental Research Grant Scheme (F01/FRGS/1605/2017). We would like to thank you the Ministry of Higher Education for funding this research.

\section{References}

Agyei-Boapeah, H., \& Machokoto, M. (2018). Allocation of internally generated corporate cash flow in Africa. Journal of Accounting in Emerging Economies, 8(4), 495-513. https://doi.org/10.1108/jaee-102017-0099

Alavipour, S. R., \& Arditi, D. (2019). Maximizing expected contractor profit using an integrated model. Engineering, Construction and Architectural Management, 26(1), 118138. https://doi.org/10.1108/ecam-04-2018-0149

Ang, J. S., \& Ding, D. K. (2006). Government ownership and the performance of government-linked companies: The case of Singapore. Journal of Multinational Financial Management, 16(1), 64-88. https://doi.org/10.1016/j.mulfin.2005.04.010

De Marco, A., Mangano, G., Corinna Cagliano, A., \& Grimaldi, S. (2012). Public financing into build-operateTransfer hospital projects in Italy. Journal of Construction Engineering and Management, 138(11), 12941302. https://doi.org/10.1061/(asce)co.1943-7862.0000545

Feng, F., Sun, Q., \& Tong, W. H. (2004). Do government-linked companies underperform? Journal of Banking \& Finance, 28(10), 2461-2492. https://doi.org/10.1016/j.jbankfin.2003.10.012

Gill-de-Albornoz, B., \& Illueca, M. (2005). Earnings management under price regulation: Empirical evidence from the Spanish electricity industry. Energy Economics, 27(2), 279-304. https://doi.org/10.1016/ j.eneco.2004.12.005

Habbash, M. (2016). Corporate governance and corporate social responsibility disclosure: Evidence from Saudi Arabia. Social Responsibility Journal, 12(4), 740-754. https://doi.org/10.1108/srj-07-2015-0088

Hanafi, M. M., Setiyono, B., \& Sanjaya, I. P. (2018). Ownership structure and firm performance: Evidence from the subprime crisis period. Corporate Governance: The international journal of business in society, 18(2), 206-219. https://doi.org/10.1108/cg-10-2016-0203

Hoang, H. C., Xiao, Q., \& Akbar, S. (2019). Trade credit, firm profitability, and financial constraints. International Journal of Managerial Finance, 15(5), 744-770. https://doi.org/10.1108/ijmf-09-20180258

Huang, X., Kabir, R., \& Zhang, L. (2018). Government ownership and the capital structure of firms: Analysis of an institutional context from China. China Journal of Accounting Research, 11(3), 171-185. https://doi.org/10.1016/j.cjar.2018.07.001

Jackowicz, K., Mielcarz, P., \& Wnuczak, P. (2017). Fair value, equity cash flow and project finance valuation: Ambiguities and a solution. Managerial Finance, 43(8), 914-927. https://doi.org/10.1108/mf-08-20160235

Kim, S. H., \& An, Y. (2018). The effect of ownership-control disparity on the Chinese firm's real activity earnings management. Pacific Accounting Review, 30(4), 482-499. https://doi.org/10.1108/par-012018-0003 
Lu, W., \& Jhuang, R. (2014). Cash flow and growth considering different ownership structure. Journal of Modelling in Management, 9(1), 5-17. https://doi.org/10.1108/jm2-04-2011-0028

Lyngstadaas, H. (2019). An empirical investigation of how information sharing affects cash flow performance through competitive capability. Supply Chain Management: An International Journal, 24(6), 710-728. https://doi.org/10.1108/scm-08-2018-0293

Mak, Y., \& Li, Y. (2001). Determinants of corporate ownership and board structure: Evidence from Singapore. Journal of Corporate Finance, 7(3), 235-256. https://doi.org/10.1016/s0929-1199(01)000219

Memon, Z. A., Chen, Y., Tauni, M. Z., \& Ali, H. (2018). The impact of cash flow volatility on firm leverage and debt maturity structure: Evidence from China. China Finance Review International, 8(1), 69-91. https://doi.org/10.1108/cfri-06-2017-0106

Nagar, N., \& Raithatha, M. (2016). Does good corporate governance constrain cash flow manipulation? Evidence from India. Managerial Finance, 42(11), 1034-1053. https://doi.org/10.1108/mf-01-20160028

Odeyinka, H. A., Lowe, J., \& Kaka, A. (2008). An evaluation of risk factors impacting construction cash flow forecast. Journal of Financial Management of Property and Construction, 13(1), 5-17. https://doi.org/ 10.1108/13664380810882048

Omopariola, E. D., Windapo, A., Edwards, D. J., \& Thwala, W. D. (2019). Contractors' perceptions of the effects of cash flow on construction projects. Journal of Engineering, Design and Technology, 18(2), 308-325. https://doi.org/10.1108/jedt-04-2019-0099

Qiang, Q. (2003). Corporate governance and state-owned shares in China listed companies. Journal of Asian Economics, 14(5), 771-783. https://doi.org/10.1016/j.asieco.2003.10.005

Shahhossein, V., Afshar, M. R., \& Amiri, O. (2017). The root causes of construction project failure. Scientia Iranica, O(0), 0-0. https://doi.org/10.24200/sci.2017.4178

Sharma, D. S. (2001). The role of cash flow information in predicting corporate failure: The state of the literature. Managerial Finance, 27(4), 3-28. https://doi.org/10.1108/03074350110767114

Talonpoika, A., Monto, S., Pirttilä, M., \& Kärri, T. (2014). Modifying the cash conversion cycle: Revealing concealed advance payments. International Journal of Productivity and Performance Management, 63(3), 341-353. https://doi.org/10.1108/ijppm-12-2012-0130

Tatum, M. C., \& Terrell, F. (2012). Hurricane reconstruction in the United States Gulf coast. International Journal of Disaster Resilience in the Built Environment, 3(3), 199-219. https://doi.org/10.1108/ 17595901211263602

Tran, N. H., \& Le, C. D. (2017). Financial conditions and corporate investment: Evidence from Vietnam. Pacific Accounting Review , 29(2), 183-203. https://doi.org/10.1108/par-07-2016-0066

Tucker, G. C., Windapo, A., \& Cattell, K. S. (2015). Exploring the use of financial capacity as a predictor of construction company corporate performance. Journal of Engineering, Design and Technology, 13(4), 596-611. https://doi.org/10.1108/jedt-10-2013-0074

Wahyudin, A., \& Solikhah, B. (2017). Corporate governance implementation rating in Indonesia and its effects on financial performance. Corporate Governance: The international journal of business in society, 17(2), 250-265. https://doi.org/10.1108/cg-02-2016-0034

Xu, L., Wang, J., \& Xin, Y. (2010). Government control, uncertainty, and investment decisions in China's listed companies. China Journal of Accounting Research, 3, 131-157. https://doi.org/10.1016/s17553091(13)60022-2

Xu, S., He, X., \& Xu, L. (2019). Market or government: Who plays a decisive role in R\&D resource allocation? China Finance Review International, 9(1), 110-136. https://doi.org/10.1108/cfri-08-2017-0190

Zuoping, X. (2011). Ownership-control rights divergence, government intervention and choice of capital structure. Nankai Business Review International, 2(3), 303-324. https://doi.org/10.1108/20408 741111155316 